\title{
UJI EFEK ANTI BAKTERI EKSTRAK BUNGA CENGKEH TERHADAP BAKTERI Streptococcus mutans SECARA IN VITRO
}

\author{
${ }^{1}$ Juvensius R. Andries \\ ${ }^{2}$ Paulina N. Gunawan \\ ${ }^{3}$ Aurelia Supit
}
${ }^{1}$ Kandidat Skripsi Program Studi Pendidikan Dokter Gigi Fakultas Kedokteran Universitas Sam Ratulangi Manado
${ }^{2}$ Program Studi Pendidikan Dokter Gigi Universitas Sam Ratulangi Manado
${ }^{3}$ Fakultas Kedokteran Universitas Sam Ratulangi Manado
Email: tara.hatana.marpaung@gmail.com

\begin{abstract}
Abstrak: Minyak cengkeh berguna sebagai antibakteri alami. Minyak esensial dari cengkeh mempunyai fungsi anestetik dan antimikrobial. Zat yang terkandung dalam cengkeh yang bernama eugenol dapat membunuh bakteri termasuk bakteri yang resisten terhadap antibiotika, salah satunya adalah bakteri Streptococcus mutans. Bakteri ini merupakan mikroorganisme penyebab utama terjadinya karies. Tujuan dari penelitian ini yaitu untuk mengetahui efek antibakteri ekstrak cengkeh terhadap bakteri Streptococcus mutans secara in vitro. Penelitian ini merupakan penelitian eksperimental menggunakan post test only control group design. Penelitian ini menggunakan bahan coba ekstrak cengkeh dengan konsentrasi 40\%, 60\%, dan 80\%, Ciprofloxacin, aquades dengan pengulangan sebanyak lima kali. Data dikumpulkan dan dianalisis dengan one-way ANOVA dan post-hoc uji LSD $(\alpha=0,05)$. Berdasarkan hasil uji statistik penelitian uji efek antibakteri ekstrak cengkeh terhadap bakteri streptococcus mutans secara in vitro, dapat disimpulkaan bahwa ekstrak cengkeh memiliki efek antibakteri dalam menghambat pertumbuhan bakteri Streptococcus mutans secara in vitro. Hasil uji lanjut post-hoc uji LSD menunjukan daya hambat ekstrak cengkeh 40\%, 60\%, 80\%, lebih kecil $(\mathrm{p}<0,05)$ dalam menghambat Streptococcus mutans secara in vitro dibandingkan Ciprofloxacin.
\end{abstract}

Kata Kunci: Ekstrak cengkeh, Streptococcus mutans.

\begin{abstract}
Clove oil is useful as a natural antibacterial agent, essential oil of clove has anesthetic and antimicrobial effect. Substances contained in clove called eugenol can kill bacteria including antibiotic resistant bacteria, one of which is the bacteria Streptococcus mutans. This bacteria is a major cause for caries. The purpose of this study was to mengetahui clove extrack antibacterial effects againts Streptococcus mutans bacteria in vitro. This study is an experimental study using a post test only control group design. This research try using clove extract with a concentration of $40 \%, 60 \%$, and $80 \%$, Ciprofloxacin, aquades repetition five times. Data collected and analyzed by one-way ANOVA and posthoc LSD test $(\alpha=0.05)$. Based on the results of the statistical test to test the effects of anti-bacterial research clove extracts against Streptococcus mutans bacteria in vitro, can disimpulkaan that clove extracts have antibacterial effects in inhibiting the growth of Streptococcus mutans bacteria in vitro.further test result post-hoc LSD test shoved its inhibitory clove extract $40 \%, 60 \%$, $80 \%$ smaller $(\mathrm{p}<0,05)$ in hibiting Streptococcus mutans in vitro compared Ciprofloxacin.
\end{abstract}

Keywords: clove extract, Streptococcus mutans

Cengkeh (Syzygium Aromaticum atau Eugenia Aromatucum), dalam bahasa inggiris disebut cloves, adalah tangkai bunga kering beraroma dari keluarga pohon Myrtaceace. ${ }^{1}$ Daun cengkeh sering kali kurang dimanfaatkan dan dianggap sebagai limbah, apabila daun cengkeh dikeringkan dan didistilasi uap dapat memperoleh minyak daun cengkeh yang bernilai ekonomi. Minyak cengkeh merupakan sumber agen antimikrobial melawan bakteri dalam mulut yang biasanya dihubungkan dengan penyakit karies gigi dan periodontal. ${ }^{1}$ Minyak cengkeh memiliki 
aktivitas biologi, antara lain sifat antibakteri, antijamur, pemberantas serangga, dan antioksidan, dan secara tradisional digunakan sebagai agen flavor dan bahan antibakteri dalam pangan. ${ }^{1}$

Minyak cengkeh merupakan salah satu bahan antibakteri alami yang jumlahnya melimpah, mudah diperoleh serta dianggap memiliki kemampuan antibakteri. ${ }^{2}$ Cengkeh menghasilkan minyak atsiri sekitar 14-21\% dimana komponen utamanya 95\% ialah eugenol. Eugenol adalah sebuah senyawa kimia aromatik, berbau, banyak didapat di butir cengkeh, sedikit larut dalam air dan larut pada pelarut organik. ${ }^{1}$

Minyak ekstrak cengkeh dapat dipakai sebagai bahan aktif atau pembuatan obat kumur karena sifatnya sebagai anti mikroba. $^{2}$ Hasil penelitian menunjukan bahwa formula obat kumur yang dihasilkan dapat menghambat tumbuhnya bakteri streptococcus mutans dan streptococcus viridians yang dapat menyebabkan terjadinya plak gigi. ${ }^{1}$ Pada zaman Dinasti Han 220 -206 SM cengkeh sudah di proses dan digunakan sebagai pewangi mulut. ${ }^{3}$

Mekanisme toksisitas fenol dalam minyak atsiri menyebabkan denaturasi protein pada dinding sel kuman dengan membentuk struktur tersier protein dengan ikatan nonspesifik atau ikatan disulfide. ${ }^{2}$ Selain itu minyak daun cengkeh juga sering digunakan dalam berbagai macam pengobatan, antara lain sebagai obat batuk, obat sakit perut, dan obat sakit gigi. Selain itu minyak atsiri juga sering digunakan untuk mengobati infeksi pada kulit. Bidang medis sering menggunakan eugonol. ${ }^{1}$

Streptococcus mutans merupakan bakteri gram positif berbentuk bulat yang khas membentuk pasangan atau rantai selama masa pertumbuhannya. Streptococcus merupakan salah satu golongan bakteri yang heterogen. ${ }^{5}$ Beberapa diantaranya merupakan anggota flora normal pada manusia. Streptococcus mutans merupakan bakteri gram positf $(+)$, bersifat non motil (tidak bergerak), berdiameter 1-2 $\mu \mathrm{m}$, bakteri anaerob fakultatif. Memiliki bentuk bulat atau bulat telur, tersusun seperti rantai dan tidak membentuk spora. ${ }^{1}$
Karies gigi merupakan penyakit infeksi dan merupakan suatu proses demineralisasi yang progresif pada jaringan keras permukaan gigi oleh asam organis yang berasal dari makanan yang mengandung gula. ${ }^{5}$ Karies gigi merupakan penyakit yang paling banyak dijumpai di rongga mulut bersama-sama dengan penyakit periodontal, sehingga merupakan masalah utama kesehatan gigi dan mulut. ${ }^{4}$

Saat ini telah dipahami bahwa karies gigi merupakan salah satu penyakit infeksi dengan penyebab multifaktorial. ${ }^{5}$ Streptococcus mutans sebagai bakteria penyebab utama terjadinya karies gigi, yang sebelumnya diketahui sebagai bagian dari flora normal dalam rongga mulut yang berperan dalam proses fermentasi karbohidrat sehingga menghasilkan asam yang pada akhirnya menyebabkan terjadinya demineralisasi gigi. ${ }^{6}$ Bakteri ini merupakan bakteri patogen pada mulut yang merupakan agen penyebab utamanya plak, ginggivitis, denture stomatitis dan karies. ${ }^{7}$ Dari beberapa penelitian terhadap bakteri yang ada di plak gigi, ternyata hanya Streptococcus mutans saja yang mempunyai korelasi positif dengan adanya karies pada permukaan gigi. ${ }^{8}$

Antibakteri merupakan substansi yang dihasilkan oleh suatu mikroorganisme (bakteri), yang mempunyai kemampuan untuk menghambat pertumbuhan ataupun membunuh mikroorganisme lain. Aktivitas antibakteri diukur secara in vitro untuk menentukan potensi agen antibakteri dalam larutan, konsentrasinya dalam cairan tubuh atau jaringan, dan kerentanan mikroorganisme tertentu terhadap obat dengan konsentrasi tertentu. Ada beberapa faktor yang mempengaruhi aktivitas antimikroba in vitro yaitu $\mathrm{pH}$ lingkungan, komponen medium, stabilitas obat, ukuran inokulum, lama inkubasi, dan aktivitas metabolik mikroorganisme. ${ }^{9}$

Golongan kuinolon yaitu Ciprofloxacin bersifat bekterisidal dan bekerja dengan menghambat DNA girase, suatu enzim yang penting dalam proses supercoiling DNA mikroba. Spekrum aktivitas antibakteri golongan ini meliputi bakteri gram negative: Enterobacteriaceae, serratia, providencia, 
P. aeruginosa, dan Streptococcus. KHM untuk berbagai mikroba ini umumnya adalah $2 \mu \mathrm{g} / \mathrm{ml}$. mikroba lain yang juga sensitive ialah Staphylococcus, N. gonorrheoeae, $H$. influenza, dan Klamida. Retensi telah terjadi pada mikroba yang kurang sensitif, Pseudomonas, beberapa strain Enterobacteriaceae, dan Staphylococcus. ${ }^{10}$

Pada penelitian Desy Enayati tahun 2009 menunjukkan bahwa ekstrak metanol bunga cengkeh yang diuji menggunakan metode dilusi memiliki aktifitas antibakteri terhadap Streptococcus mutans. Berdasarkan hal ini, penulis tertarik untuk menguji efek antibakteri dari penggunaan ekstrak cengkeh terhadap bakteri Streptococcus mutans secara in vitro dengan menggunakan metode sumuran.

\section{BAHAN DAN METODE}

Penelitian ini merupakan penelitian eksperimental dengan pendekatan post test only control group design yang dilaksanakan pada Maret-Juli 2014 di laboratorium parasitologi Fakultas Kedokteran Universitas Sam Ratulangi Manado. Sampel pada penelitian ini ialah koloni bakteri Streptococcus mutans. Alat yang digunakan yaitu Petridish, Tabung reaksi, Pinset, Kapas lidi steril, Sterilisator, dry heat, Inkubator, Anaerobic jar, Api bunsen, Object glass, Mikroskop, Jangka sorong, Sendok plastik, Timbangan, Tabung erlenmeyer, Microwave, Kamera, Spidol, Perforator Refrigerator, Labu ekstraksi, Kondensor, dan Waterbath. Bahan penelitian ini yaitu Minyak cengkeh, Bakteri Streptococcus mutans, $\mathrm{NaCl}$ 0,9\%, Kristal violet, Lugol, Safranin, Alkohol 96\%, Minyak emersi, Agar darah, Brain heart infusion (BHI), Aquabidest steril Etanol.

Tahap pertama ialah Bakteri yang telah dipesan dari Fakultas Kedokteran Gigi Universitas Hasanuddin Makassar ditempatkan dalam wadah botol kaca steril dalam dua media yakni agar miring dan media BHI-B kemudian dimasukkan ke dalam tas untuk selanjutnya dibawa ke daerah penelitian, setelah tiba bakteri tersebut disimpan di dalam refrigerator.
Tahap kedua ialah Bunga cengkeh yang sudah kering di belender halus, kemudian disaring menggunakan ayakan tepung hingga didapatkan bubuk cengkeh kering. Kemudian bubuk cengkeh ditimbang sebanyak 100 gr dan ditempatkan diwadah tertutup. Masukkan bubuk cengkeh ke dalam labu ekstraksi, tambahkan pelarut etanol sebanyak $400 \mathrm{ml}$, kemudian di refluks, alirkan air pendingin melalui kondensor, kemudian pasangkan labu ekstraksi kedalam air mendidih dalam waterbath kemudian di refluks selama 3 jam, lalu hasil refluks disaring menggunakan kertas saring untuk memisahkan ampas yang mungkin masih terikut ketika proses refluks sehingga didapatkan filtrat-nya, kemudian filtrat di evaporasi untuk menguapkan pelarut etanol yang masih tercampur, sehingga diperoleh ekstrak murni cengkeh (Gambar 6). Hasil ekstrak ditempatkan pada media tertutup dan terhindar dari paparan cahaya matahari langsung, dan dimasukkan ke dalam refrigerator.

Tahap ketiga ialah larutan ekstrak cengkeh diencerkan dengan etanol. Dalam membuat ekstrak cengkeh konsentrasi 40\%, $60 \%$, dan $80 \%$ yaitu dengan cara mengambil larutan induk sebanyak $200 \mathrm{ml}$, kemudian dipisahkan menjadi $40 \mathrm{ml}, 60 \mathrm{ml}$, dan $80 \mathrm{ml}$. Masing-masing konsentrasi dibuat dengan cara melarutkan $40 \mathrm{ml}$ ekstrak cengkeh dilarutkan dengan larutan etanol sebanyak $60 \mathrm{ml}, 60 \mathrm{ml}$ ekstrak cengkeh dilarutkan dengan larutan etanol sebanyak $40 \mathrm{ml}$, dan $80 \mathrm{ml}$ ekstrak cengkeh dilarutkan dengan 20 $\mathrm{ml}$ larutan etanol, sehingga masing-masing konsentrasi menjadi $100 \mathrm{ml}$. Setelah dilarutkan tempatkan ekstrak cengkeh pada media tertutup dan masukkan ke dalam refrigerator.

Tahap keempat ialah Petridish, tabung reaksi, pinset, object glass, dan tabung erlenmeyer dicuci terlebih dahulu dengan sabun antiseptik dan dimasukkan ke dalam sterilisator dry heat bersama dengan kapas lidi steril untuk disterilkan dengan suhu 170 ${ }^{\circ} \mathrm{C}$ selama 10-15 menit sedangkan untuk media disterilkan (sterilisasi basah) dalam autoclave pada suhu $121^{\circ}$ selama 2 jam. BHI ditimbang sebanyak 9,3 gram lalu 
dicampur dengan aquades sebanyak $250 \mathrm{ml}$ dalam tabung erlenmeyer dan dipanaskan di kompor listrik selama 15 menit. Setelah itu, dimasukkan ke dalam inkubator selama 15 menit. Kemudian dituang ke botol steril lalu didinginkan pada suhu ruangan. Agar darah ditimbang sebanyak 5 gram lalu dicampurkan dengan $125 \mathrm{ml}$ aquades dalam tabung Erlenmeyer dan dipanaskan di atas kompor listrik selama 15 menit. Setelah itu dibiarkan dingin selama \pm 15 menit dan dicampur dengan darah manusia golongan darah "O" sebanyak 5cc. Selanjutnya dimasukkan ke inkubator selama 15 menit. Lalu dituang ke dalam cawan petri steril. Laher sebanyak 3 buah dengan diameter $6 \mathrm{~mm}$ yang telah disterilkan sebelumnya, diletakkan tegak lurus dengan jarak yang seragam satu sama lain dan dibiarkan dingin pada suhu ruangan. Laher diangkat dengan pinset setelah media mengeras sehingga terbentuk 3 buah sumur.

Tahap kelima ialah Bakteri yang diambil dari stok bakteri murni diuji kebenarannya dengan cara pengecatan atau pewarnaan gram. Bakteri ditaruh di object glass yang sebelumnya telah ditetesi dengan $\mathrm{NaCl}$ 0,9\% kemudian difiksasi dengan api bunsen.

Tahap keenam ialah Bakteri yang diperoleh dari stok bakteri murni Fakultas Kedokteran Gigi Universitas Hasanudin Makassar yang tersedia dalam media BHI-B kemudian diperbanyak dengan menggunakan media BHI-B dari Laboratorium Mikrobiologi Fakultas Kedokteran Universitas Sam Ratulangi dengan perbandingan 1 : 3 (200 gr : 600 gr). Setelah itu dimasukkan ke dalam anaerobic jar dan diinkubasi pada suhu $37^{\circ} \mathrm{C}$ selama 24 jam.

Metode yang digunakan dalam penelitian ini yaitu metode difusi lempeng agar. Media agar darah disediakan sebanyak 9 petridish. Streptococcus mutans diambil dari stok bakteri murni dari FKG UNHAS Makassar. Bakteri tersebut diperbanyak dengan memasukkannya dalam petridish yang berisi media BHI-B lalu dimasukkan ke dalam anaerobic jar dan diinkubasi pada suhu $37{ }^{\circ} \mathrm{C}$ selama 24 jam. Kemudian bakteri dioles dengan menggunakan kapas lidi steril pada permukaan media agar darah, selanjutnya pada media agar darah yang telah dibuatkan lubang sumuran dengan diameter $6 \mathrm{~mm}$ dioleskan bakteri Streptococcus mutans pada dinding sumuran.

Pada lubang sumuran diberi bahan ekstrak cengkeh dengan konsentrasi 40\%, $60 \%$, dan $80 \%$, serta ciprofloxacin 500mg yang telah dihaluskan dan ditimbang sebanyak 100mg dilarutkan dengan larutan aquabides sebanyak $200 \mathrm{ml}$ sebagai variabel kontrol positif dan lubang sumuran terakhir diberi larutan aquabides steril sebagai kontrol negatif.

Setelah semua bahan penghambat dimasukkan ke lubang sumuran masingmasing petridish, lalu diinkubasi ke dalam anaerobic jar selama 24 jam.

Setelah 24 jam, daerah bening atau zona hambat yang terbentuk pada media agar darah pada masing-masing sumuran yang diberi bahan coba, diukur diameternya dengan jangka sorong dan diameter zona hambat dapat diukur dengan rumus: (Gambar 1)
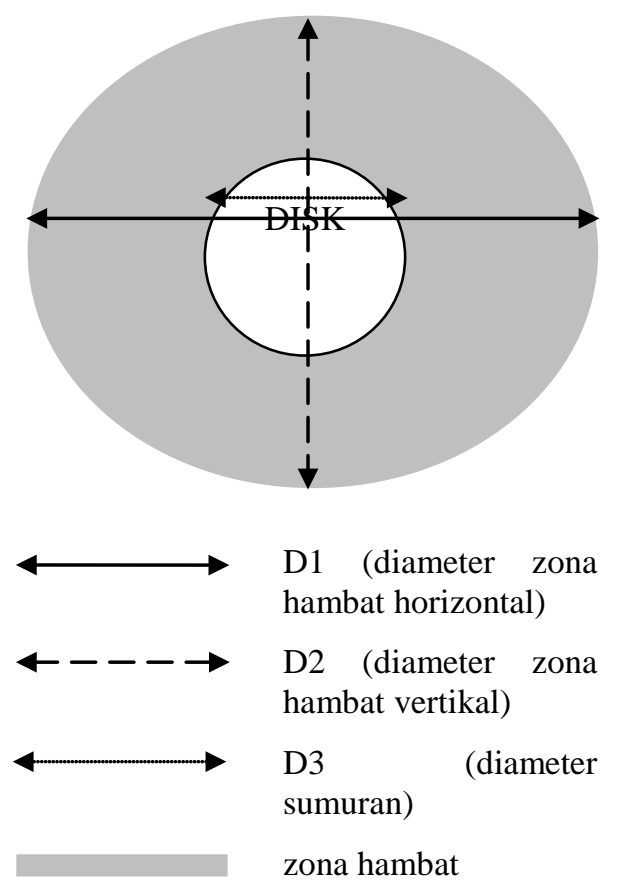

$\mathrm{L}=\frac{(\mathrm{D} 1-\mathrm{D} 3)+(\mathrm{D} 2-\mathrm{D} 3)}{2}$

$\mathrm{L}=\frac{(\mathrm{D} 1-6,35)+(\mathrm{D} 2-6,35)}{2}$

Keterangan:

$\mathrm{L}$ = Luas zona hambat

Gambar 1. Diagram zona hambat 
Andries, Gunawan, Supit; Uji Efek Antibakteri Ekstrak Bunga Cengkeh...

\section{HASIL PENELITIAN}

Dari pengamatan yang dilakukan, zona hambat yang terbentuk dalam penelitian ini bisa dilihat pada Gambar 1. Setelah diukur, diameter zona hambat dihitung dengan rumus lalu dimasukkan pada tabel pengamatan. Dari pengamatan yang dilakukan terhadap penelitian ini, ditemukan zona hambat atau zona bening di sekitar cakram yang berisi bahan coba yaitu ekstrak cengkeh dan Ciprofloxacin (100mg).

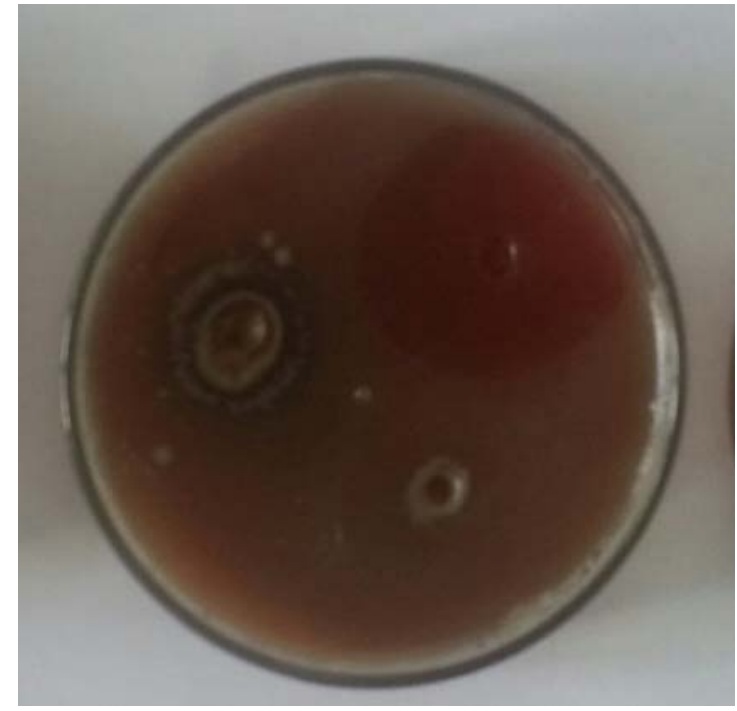

Gambar 2. Zona daya hambat yang terbentuk

Tabel 1. Tabel pengamatan Luas Zona Hambat $\left(\mathrm{mm}^{2}\right)$

\begin{tabular}{cccc}
\hline \multirow{2}{*}{ Bahan coba } & \multicolumn{3}{c}{ Luas Zona Hambat $\left(\mathrm{mm}^{2}\right)$} \\
\cline { 2 - 4 } & \multicolumn{3}{c}{ Pengulangan } \\
\cline { 2 - 4 } & I & II & III \\
\hline Cengkeh 40\% & 20,41 & 16,36 & 19,71 \\
Cengkeh 60\% & 21 & 21,2 & 16,91 \\
Cengkeh 80\% & 25,81 & 32,3 & 28,9 \\
Ciprofloxacin & 35,86 & 39,36 & 37,86 \\
aquades & 00 & 00 & 00 \\
\hline
\end{tabular}

Probabilitas normalitas data mempunyai distribusi normal ( $\mathrm{p}>0,05$ ). Setelah diketahui data mempunyai distribusi normal, maka untuk mengetahui terdapatnya perbedaan yang signifikan antara bahan coba secara statistik, dilakukan uji parametik One-way ANOVA dengan taraf kemaknaan 5\% (Tabel 2).
Tabel 2. Rerata dan standar deviasi diameter zona hambat $\left(\mathrm{mm}^{2}\right)$

\begin{tabular}{|c|c|c|c|}
\hline Bahan Coba & $\mathrm{n}$ & $\bar{x} \pm \mathrm{SD}$ & $\mathrm{p}$ \\
\hline $\begin{array}{l}\text { Ekstrak cengkeh } \\
40 \%\end{array}$ & 3 & $18,83 \pm 2,16$ & $<0,001$ \\
\hline $\begin{array}{l}\text { Ekstrak cengkeh } \\
60 \%\end{array}$ & 3 & $19,70 \pm 2,42$ & $<0,001$ \\
\hline $\begin{array}{l}\text { Ekstrak cengkeh } \\
80 \%\end{array}$ & 3 & $29.02 \pm 3,24$ & $<0,001$ \\
\hline $\begin{array}{l}\text { ciprofloxacin } \\
\text { (100mg) }\end{array}$ & 3 & $37,70 \pm 1,75$ & $<0,001$ \\
\hline Aquades & 3 & $00,00 \pm 00,00$ & $<0,001$ \\
\hline
\end{tabular}

Hasil uji ANOVA didapatkan probabilitas $0,00 \quad(\mathrm{p}<0,05)$, maka dapat dinyatakan bahwa $\mathrm{H}_{0}$ ditolak (Tabel 2).

Kelompok perendaman yang bermakna ialah yang mempunyai signifikansi kurang dari 0,05 $(\mathrm{p}<0,05)$. Hasil uji post-hoc LSD, menunjukkan nilai probabilitas dari masingmasing kelompok bahan coba, yaitu sebagai berikut:

1. Kelompok bahan coba yang tidak terdapat perbedaan yang bermakna yaitu antara kelompok bahan coba ekstrak cengkeh $40 \%$ dan ekstrak cengkeh $60 \%$.

2. Kelompok bahan coba yang terdapat perbedaan yang bermakna yaitu antar kelompok ekstrak cengkeh 60\% dengan ekstrak cengkeh 80\%, ekstrak cengkeh $60 \%$ dengan ciprofloxacin, ekstrak cengkeh 60\% dengan aquades, ekstrak cengkeh $80 \%$ dengan ekstrak cengkeh $40 \%$, ekstrak cengkeh $80 \%$ dengan ciprofloxacin, ekstrak cengkeh 80\% dengan aquades, ciprofloxacin dengan ekstrak cengkeh 40\%, ciprofloxacin dengan aquades, dan aquades dengan ekstrak cengkeh $40 \%$.

\section{BAHASAN}

Pada prinsip penelitian dalam uji toksisitas pemilihan konsentrasi terendah dipilih konsentrasi yang tidak memberikan zona hambat, dan konsentra tertinggi dipilih berdasarkan konsentrasi terendah dan konsentrasi tertinggi dapat menghasilkan zona hambat paling besar. Pada peneltian 
sebelumnya telah dilakukan peneltian dengan konsentrasi terendah $1 \%$ dan konsentrasi tertinggi $20 \%$, dimana $1 \%$ ekstrak cengkeh pada peneltian sebelumnya tidak memberikan zona hambat. ${ }^{24}$ Sehingga pada penelitian ini peneliti ingin meneliti efek antibakteri ekstrak bunga cengkeh pada setiap interval $20 \%$ yaitu $40 \%$, 60\%, dan $80 \%$.

Pada penelitian ini konsentrasi ekstrak cengkeh 40\%, 60\%, dan 80\% mempunyai daya hambat. Ekstrak cengkeh dengan 40\% dan $60 \%$ memilki zona hambat yang lebih kecil dari zona hambat ekstrak cengkeh 80\%. Bahan coba ekstrak cengkeh menunjukan adanya penambahan luas zona daya hambat setiap penambahan konsentrasi. Hal ini disebabkan semakin besar konsentrasi ekstrak cengkeh yang terdapat dalam medium, maka jumlah ekstrak cengkeh yang berdifusi ke dalam sel bakteri semakin meningkat sehingga menyebabkan terganggunya pertumbuhan diameter koloni bakteri Streptococcus mutans atau bahkan menyebabkan kematian pertumbuhan. ${ }^{11}$

Penelitian ini sejalan dengan penelitian yang dilakukan oleh Kumala dan Indriani mengenai efek antibakteri ekstrak etanol daun cengkeh (Eugenia aromatica), di mana pada setiap peningkatan konsentrasi dari $1 \%$, 10\%,dan 20\% menunjukan peningkatan luas zona hambat. Semakin tinggi konsentrasi ekstrak cengkeh, makin besar pula zona hambat yang terbentuk. ${ }^{11}$

Terbentuknya zona hambatan di sekitar sumur sampel menunjukkan ekstrak cengkeh mengandung eugenol yang dapat membunuh bakteri termasuk bakteri yang resisten terhadap antibiotika. ${ }^{12}$ Mustika dan Rahmat, menyatakan bahwa konsentrasi suatu bahan yang berfungsi sebagai antimikroba merupakan salah satu faktor penentu besar kecilnya kemampuan dalam menghambat pertumbuhan mikroba yang diuji. 13

Berdasarkan hasil pengamatan, dari 3 kali pengujian dengan menggunakan sumuran yang diberi larutan ekstrak cengkeh, semuanya menunjukkan adanya zona hambat yang cukup besar di sekeliling sumur tersebut. Apabila dibandingkan dengan zona hambat yang berada di sekeliling sumuran Ciprofloxacin (100mg) luas zona hambat yang terbentuk lebih besar dibanding dengan sumuran ekstrak cengkeh, sedangkan sumuran yang digunakan sebagai kontrol negatif (aquades) tidak membentuk zona hambat. Hal ini sejalan dengan penelitian yang dilakukan oleh Aneja dan Joushi tentang daya hambat ekstrak metanol dari cengkeh terhadap Streptococcus mutans di mana luas zona hambat yang dibentuk oleh ekstrak metanol cengkeh $\left(11,64 \mathrm{~mm}^{2}\right)$ lebih kecil dari luas zona hambat yang dibentuk oleh Ciprofloxacin $\left(27,32 \mathrm{~mm}^{2}\right){ }^{14}$

Pada Tabel 3 dapat dilihat bahwa setiap konsentrasi ekstrak cengkeh memiliki nilai rata-rata diameter zona hambat lebih besar dibanding dengan diameter zona hambat kontrol negatif dalam penelitian ini yaitu aquades. Hal ini menunjukkan bahwa ekstrak cengkeh memiliki kemampuan untuk menghambat pertumbuhan bakteri Streptococcus mutans. Ekstrak cengkeh mampu menekan pertumbuhan bakteri Streptococcus mutans dengan mengganggu permeabilitas membran sel, menghambat sintesis dinding sel, serta menghambat fungsi membran sitoplasma. Hasil ini sejalan dengan penelitian yang dilakukan secara in vitro oleh Aulifa tentang aktivitas antibakteri ekstrak metanol dari tumbuhan rempah-rempahan yang membuktikan bahwa dari kelima ekstrak metanol yang memiliki presentase daya hambat paling tinggi adalah ekstrak metanol bunga Syzygium aromaticum. ${ }^{15}$

Dari penelitian ini diketahui bahwa terdapat perbedaan luas zona hambat yang terbentuk hal ini terlihat dari adanya variasi zona pada masing-masing bahan coba. Perbedaan ini dapat disebabkan oleh beberapa faktor, antara lain besarnya inokulum, waktu inkubasi, konsentrasi ekstrak, dan daya antibakteri zat berkhasiat. Makin besar inokulum maka semakin kecil daya hambatnya, sehingga semakin kecil zona yang terbentuk. Konsentrasi ekstrak memengaruhi kecepatan difusi zat berkhasiat. Makin besar konsentrasi ekstrak, maka makin cepat difusi, akibatnya makin besar daya antibakteri dan makin luas diameter zona hambat yang terbentuk. Hal 
ini sesuai dengan hasil penelitian bahwa ekstrak dengan konsentrasi 80\% mempunyai zona hambat yang lebih besar dibanding dengan ekstrak konsentrasi $40 \%$ dan $60 \%{ }^{11}$

\section{SIMPULAN}

Berdasarkan hasil penelitian uji efek anti bakteri ekstrak cengkeh terhadap bakteri Streptococcus mutans secara in vitro, dapat disimpulkan bahwa ekstrak cengkeh memiliki efek anti bakteri dalam menghambat pertumbuhan bakteri Streptococcus mutans secara in vitro.

\section{SARAN}

Diharapkan dapat dilakukan penelitian lebih lanjut mengenai ekstrak cengkeh terkait manfaatnya terhadap dalam menghambat bakteri lain yang merugikan dalam rongga mulut. Dapat dijadikan masukan agar ekstrak cengkeh bisa menjadi alternatif antibakteri khususnya dibidang kedokteran gigi.

\section{DAFTAR PUSTAKA}

1. Suryanto E. Fitokimia Antioksidan. Surabaya: CV. Putra Media Nusantara; 2012.h.165-6.

2. Kristijanto AI, Soetjipto H, Purtanto FT. Ekstak kasar limbah cengkeh (Syzygium aromaticum L.) fraksi heksan sebagai larvisida alami terhadap jentik nyamuk demam berdarah (Aedes aegypti Linn.) instar II dan IV. Prosidang seminar Nasional sains dan pendidikan sains VII UKWS: [serial online]. 2010.h.207-217. [diakses 29 Maret 2014]. Tersedia dalam: URL: http://repository.library.uksw.edu/handle/12 3456789/3062

3. Nurdjanah N. Diversifikasi penggunaan cengkeh. Balai Besar Penelitian Dan Pengembangan Pasca Panen Pertanian Bogor. [serial online]. 2004;3(2):63-9. [diakses 29 Maret 2014]. Tersedia dalam: URL: http://perkebunan.litbang. deptan.go.id/upload.files/File/publikasi/pers pektif/Perspektif_vol_3_No_2_3_Nanan.pdf

4. Theodore M, Harald O, Edward J. Sturdevant's art and science of operative dentistry. $4^{\text {th }}$ ed. St. Louis, Missouri: Mosby, Inc; 2002.p.65, 67, 80, 83-85, 89.
5. Bahar A. Paradigma baru pencegahan karies gigi. Jakarta: Fakultas Ekonomi Universitas Indonesia; 2011.h.93.

6. Zaenab, dkk. Uji antibakteri siwak (Salvadora persica Linn.) terhadap Streptococcus mutans (ATC31987) dan Bacteroides melaninogenicus. Makara Kesehatan; [serial online]. 2004; 8(2):h.3740.[diakses 16 Mei 2014]. Tersedia dalam: URL: http://journal.ui.ac.id/health/ article/download/287/283

7. Syahrurachman, Agus. Buku Ajar Mikrobiologi kedokteran, edisi Revisi. Jakarta: Binarupa Aksara; 1994.h.180.

8. Nugraha AW. Plak dimana-mana. Yogyakarta: Fakultas farmasi. [serial online]. 2008.h.1-3. Tersedia dalam: URL: http://mikrobia.files.wordpress.com/2008/05 /streptococcus mutans_31.pdf. [diakses 16 Mei 2014].

9. Yosephine AD. Mouthwash formulation of basil oil (ocimum basilicum l) and in vitro antibacterial and antibiofilm activities against Streptococcus mutans. Traditional Medicine Journal: [serial online]. 2013;2(3): p.18-22. Available from: URL: http:// mot.farmasi.ugm.ac.id/files/245.\%202\%20K olom\%20Puji.pdf. Accesed May 1st, 2014.

10. Staf pengajar Departemen Farkologi Fakultas Kedokteran Universitas Sriwijaya. Kumpulan kuliah Farmakologi, edisi 2. Jakarta: EGC. 2009. hal.636

11. Kumala S, Indriani D. Efek antibakteri ekstrak etanol daul cengkeh (Eugnia aromatic L.). Jurnal Farmasi Indonesia 2 juli 2008; 4(2):82-7.

12. Evirza TD. Daya Hambat Ekstrak Bunga Cengkeh (Syzygium aromaticum L.) Terhadap Trichophyton mentagrophytes Dan Candida albicans Secara In Vitro. Jakarta: Fakultas Farmasi Universitas Pancasila. 2013. Skripsi. h.38.

13. Mustika, I. dan A.S. Rahmat. Efikasi Beberapa Macam Produk Cengkeh dan Tanaman Lain terhadap Nematoda Lada. Proceeding Seminar Hasil Penelitian dalam Rangka Pemanfaatan Pestisida. Bogor. 1993. h.40.

14. Aneja KR, Joshi R. Antimicrobial activity of Syzygium aromaticum and its bud oil against dental cares causing microorganisms. Available at: URL: http://www.msk.or.kr/jsp/downloadPDF1.js p?fileName=45(5)_13.pdf. $\quad$ Accesed Augustus 1st, 2014. 
Jurnal e-GiGi (eG), Volume 2, Nomor 2, Juli-Desember 2014

15. Aulifa DL, Aryantha INP, Sukarsono. aktivitas anti jamur ekstrak metanol dari tumbuhan rempah-rempah. Bionatura jurnal ilmu-ilmu hayati dan fisik Maret 2014; 16(1):

12-18. 